\title{
The genus Ptychogaster
}

\author{
JOOST A. STALPERS
}

STALPERS, J. A. 2000: The genus Ptychogaster. - Karstenia 40: 167-180. Helsinki. ISSN 0453-3402.

All species classified in the genera Ptychogaster Corda and Ceriomyces Corda have been studied. Ptychogaster is now restricted to anamorphs of Postia (Bull. : Fr.) Singer. Sporotrichopsis Stalpers is described for the anamorph of Abortiporus biennis Fr. and Caeruleomyces Stalpers to accomodate Sporotrichum azureum Arx. An annotated check-list of all species ever classified in Ptychogaster and Ceriomyces is given.

Key words: Caeruleomyces, Ceriomyces, polypores, Ptychogaster, Sporotrichopsis, taxonomy

Joost A. Stalpers, Centraalbureau voor Schimmelcultures, P.O. Box 85167, NL-3508 AD Utrecht, The Netherlands

Ptychogaster was described in 1838 by Corda with only one species, $P$. albus Corda. The genus was soon used to accomodate anamorphs of polypores in the widest sense. The type species, $P$. albus, is the anamorph of the well-known Polyporus ptychogaster Ludwig, currently classified in Postia (or Oligoporus or Tyromyces s.1.) (Donk 1933, 1962). Ptychogaster was synonymized with Ceriomyces Corda by Patouillard (1900), but the type (and only original) species, C. fischeri Corda, is a nomen dubium (Donk 1960). Nevertheless Ceriomyces has been considered the correct name for this group of fungi for some time, and Clements \& Shear (1931) proposed C. albus as the type, which would have made it a typonym of Ptychogaster. The species described in the genus are now classified in different families and orders: Poriales, Ganodermatales, Hymenochaetales, while also anamorphs of the Corticiaceae and Podoscyphaceae have been classified here.

\section{Materials and methods}

Isolates were grown in polystyrene Petri dishes on neutralized 2\% malt extract agar (MEA) and cherry decoction agar ( $\mathrm{ChA}, \mathrm{pH} \mathrm{4-5)}$ at room temperature in diffuse daylight. Description method and enzyme tests are according to Stalpers (1978). Microscopical slides were examined with aniline blue in lactic acid. Capitalized colour names refer to Ridgway (1912).

Material examined (data on CBS cultures are not given here. They can be found in the CBS catalogue or on-line on the CBS homepage: http://www.cbs.knaw.nl).

Abortiporus biennis: Argentina, Quilmes, IV.1904 Spegazzini 408.20 (lectotype of Ceriomyces pulchellus, LPS); La Plata, 11.III.1910 (sub Ceriomyces pulchellus, LPS); Boca del Riachuelo, 4.IV.1880 Schnyder \& Spegazzini 40818 (type of Ceriomyces schnyderianus, LPS). Australia, South Australia Adelaide, J. Burton Cleland 25149. Cultures: CBS 133.42, 373.59, 676.70, 365.74, 520.85, 224.93

Amylocystis lapponicus: Culture: CBS 815.72

Caeruleomyces azureum: Culture: CBS 609.71

Ceriomyces incomptus: Australia, Kangaroo Island, no 3501, 24.IV.1889 (PAD; type).

Cymatoderma pallens: Culture: CBS 327.66

Ganoderma colossus Cultures: CBS 216.36, 267.88, 268.88 .

Ganoderma oerstedii: Culture: CBS 514.92.

Ganoderma rufoalbum: West-Africa, Ashanti, $T$. Hunter 238, Lloyd 25153 (type of Ptychogaster africanus, BPI). - Ibidem, Hunter 246 (Lloyd 19997 BPI). Congo, on trunk, Thoilon (type of Ptychogaster lycoperdon, FH, Herb. Patouillard). St. Thomé (type of Ptychogaster rufoalbus, FH, Herb. Patouillard).

Ganoderma weberianum: Culture: CBS 219.36.

Granulobasidium vellereum: Cultures: CBS 214.54, $165.65,152.84$. 
Hymenochaete rubiginosa: Culture: CBS 237.39.

Inonotus rickii: Cuba (type of Ptychogaster cubensis, PC). Brazil, Bahia, on wood, C. Torrend \& Lloyd $55501 B$ (type of Ptychogaster lucidus, BPI). Cultures: CBS 304.78, 305.78

Oxyporus obducens: China, Yunnan (type of Ptychogaster effusus, FH). France, Gournay-en-Brie, on trunk of Salix, III.1890 Patouillard (as Poria mollusca Pers., FH). Germany, Pfaueninsel, on root stump of cf. Prunus, 4.X.1968 H. Jahn (herb. Jahn). Czech Republic, Pruhonice near Praha, in garden, in cavity of living Aesculus hippocastani, F. Kotlaba (herb. Jahn). Bohemia, Libcic, on cavity of living trunk of Ulmus sp., 6.X.1963 Z. Pouzar (herb. Jahn). Germany, Rheinland, Kerpen, Erftauwald near Kerpener Bruch, on Ulmus 'Scheitholz', 8.I.1968 H. Gorholt, (herb. Jahn), Brandenburg, Kreis Zossen near Siethen, in cavity of Acer sp., D. Benkert, herb. Jahn); Rheinland, Kerpen, on Populus, 22.X.1976 H. Gorholt (herb. Jahn); Teutoburger Wald, Donoper Teich near Hiddeser Bent am Krebsteich, on angiospermous wood, 20.X.1979 H. Jahn (herb. Jahn); West Berlin, Tegeler Forst near Gästehaus, on cf. Populus platanoides, 16.XI.1967 A. Straus (herb. Jahn). Culture: CBS 578.88.

Parmastomyces mollissimus: Cultures: CBS 427.48, 293.71.

Phellinus bambusinus: Vietnam, Ke' So', on old bamboo, 28.VII.1890 Bon 4468 (type, FH).

Postia floriformis: (With conidia) Sweden, Upland, Upsala, Botanic garden, Victoria House, on wooden flowerbox in hothouse, 18.X.1947 J. Eriksson \& J.A. Nannfeldt (L). Norway, Oslo, Gaustad, on cf. Pinus, 11.IX.1972 L. Ryvarden (O). (Without conidia) Estonia, Kilingi-Nõmme, on trunk and root of Picea (L) (not typical). USA, Great Smoky Mountains National Park, Newfound Gap, on gymnospermous wood, 7.VIII.1949
Lowe 3748 (L). Netherlands, Hilversum, on wooden pole (probably Picea), 28.X.1965 J.B.M. Frencken (L).Germany, Kreis Lichtenfels, Grosser Wildhugel near Weidhausen, MTB 5832, H. Engel. (O). Cultures: CBS $253.84,557.85,558.85,559.85,560.85,711.85$, 278.89 .

Postia guttulata: Culture: CBS 358.33, 519.85.

Postia ptychogaster: Netherlands, Gelderland, Hoge Veluwe, on branchlets of gymnosperm, 7.VIII.1960 W. Sommer-Henniphaas (L); Drente, Lheebroekerzand, Poort twee, on stumps of Pinus, 25.IX.1960 M.A. Donk (L). Germany, Bavaria, forest near Wertheim, on very rotten coniferous stump, 2.X.1962 M.A. Donk (L); Königstein, Fungi Rhenani exsicc. 1882 L. Fuckel (L). Cultures: CBS 144.75, 711.84, 712.84, 713.84.

Postia rennyi: Finland, Tavastia australis, Tammela, Mustiala, in Bjerkandera destructor, 20.X.1891 P.A. Karsten 1245 (lectotype of Sporotrichum isabellinum); ibidem 1242, 1243, $1244(\mathrm{H})$. France, in Pinetum, on gymnospermous wood, IX.1890 E. Boudier (type, PC). Netherlands, Hilversum, on wood of Pinus sylvestris, IX.1973 J.A. Stalpers (CBS). Cultures: CBS 929.72, 259.74, 334.81, 301.82, 516.85, 918.87. PC).

Ptychogaster fici: Tunisia, on Robinia, X.1892 (type,

Punctularia atropurpurascens: Cuba, on dead wood $C$. Wright 454 (herb. Berkeley H 269/80-3, type of Reticularia affinis, K); C. Wright (herb. Berkeley H 269/80-4, type of Reticularia atrorufa, K); C. Wright 675 (herb. Berkeley H 269/80-5, type of Reticularia venulosa, K); C. Wright 542, Fungi Cubenses Wrightiani (K). Sri Lanka (Ceylon), XI.1867 G.M.K.J. 84 (sub Reticularia venulo$s a, \mathrm{~K})$. Cultures: CBS 259.38, 388,66, 407.72, 317.75, $318.75,418.86,419.85,420.86,421.86,422.86$, $423.86,424.86,425.86,426.86$.

\section{Key to cultures of Aphyllophorales producing an anamorph in Ptychogaster s.l.}

1a. Large, more or less globose, intercalary chlamydospores present ........................................... 2

1b. Large intercalary chlamydospores absent

2a. Clamps present, except at marginal hyphae (incl. Tyromyces trichrous)

Aurantiporus, Climacodon, Hapalopilus

2b. Clamps absent or very rare. Anamorph: Sporotrichum

3a. Causing a brown rot, reaction with alpha-naphthol negative. On gymnosperms .................... 4

3b. Causing a white rot, reaction with alpha-naphthol positive. Preferably on angiosperms ......... 5

4a. Conidia single, 7.5-13 $\times 5-9 \mu \mathrm{m}$, becoming very thick-walled .............. Amylocystis lapponicus

4b. Conidia at least when old in chains, smaller, becoming slightly thick-walled. Anamorph: Ptychogaster Postia

5a. Clamps present, except at the very margin. ....................................................... Spongipellis

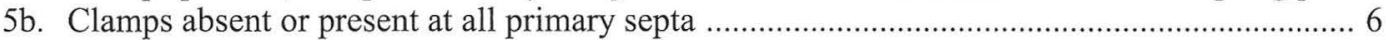

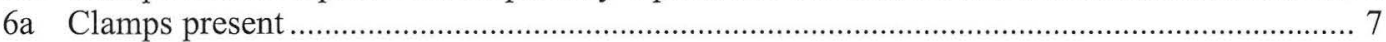

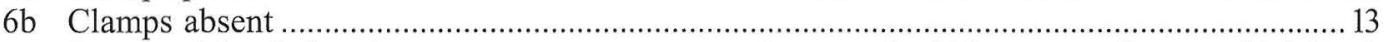

7a. Encrusted hyphal ends present ....................... Anamorph of Tyromyces chioneus (Fr.) Donk

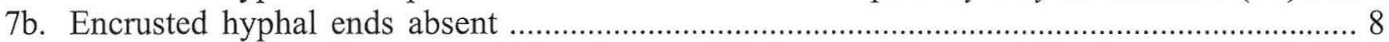

8a. Colony becoming blue or purplish red to purplish brown. Gloeocystidia absent ................... 9 
$8 \mathrm{~b}$ Colony white to cream-coloured or pink. Gloeocystidia present or absent.....

9a. Colony blue when grown in the light. Conidia terminal, subcylindrical to ovoid or pyriform, $(7-) 8.5-16(-21) \times 4.5-7(-8) \mu \mathrm{m}$. Anamorph: Caeruleomyces verae

9b. Colony purplish red or purplish brown to vinaceous drab. Conidia in chains, subglobose to ellipsoid or ovoid, $4-7(-10) \times 3-4.5 \mu \mathrm{m}$.

Punctularia atropurpurascens

10a. Gloeocystidia present (Sporotrichopsis) .. 11

10b. Gloeocystidia absent. 12

11a. Thick-walled skeletoid hyphae present Abortiporus biennis

11b. Thick-walled skeletoid hyphae absent ......................................... Granulobasidium vellereum

12a. Branched skeletal hyphae present. Chlamydospores often ornamented or mainly

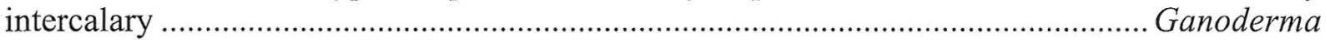

12b. All hyphae thin-walled. Conidia terminal, smooth, globose to pyriform and then often broader than long, 8-12 × 8-14 $\mu \mathrm{m}$. Anamorph: Sporotrichum sporodochiale

13a. Colony white to cream coloured. Conidia in long, often branched chains. Setae and setal hyphae absent. Oxyporus obducens

13b. Colony with ochraceous to brown tinges. Setae or setal hyphae often present.... Hymenochaetales

\section{Poriales}

\section{Postia Fr. (= Oligoporus Bref.)}

Anamorph: Ptychogaster Corda, type: Ptychogaster albus Corda

Cultures are generally powdery to pulverulentfloccose or low cottony-woolly when young, margin appressed to downy, colour whitish to cream-coloured when young, often becoming pink, ochraceous, tawny or vinaceous to dark brown. Hyphae hyaline, thin- to in some species thick-walled, 1.5-7 $\mu \mathrm{m}$ wide, with abundant clamps. Branching equivalent or inequivalent. Clamps often with a central hole, regularly sprouting to form a hypha. Conidiogenous hyphae indiscrete, branched, often from clamps, about $2 \mu \mathrm{m}$ wide, typically slightly swollen at the apex, with a clamp at some distance from the swelling. During conidiogenesis a simple septum is layed down at the base of the swelling or if the swelling is indistinct or absent, at some distance above the last clamp. The wall between the clamp and the simple septum disintegrates and the conidium is liberated. Sometimes another simple septum is formed at the basal and/or more rarely at the apical part of the conidium; the cytoplasm then withdraws to the largest cell, which then functions as (secondary) conidium. Conidia also formed in botryose clusters and then often only terminal. Conidia when young thin-walled, ellipsoid to cylindrical sometimes angular, when mature rounding off and becoming thick-walled and coloured. After liberation the conidium may become more rounded and more thick-walled, which often goes with a reduction of the maximum size. Crystals present, bipyramidal or prismatic. Growth rate very slow to moderate, $2-35 \mathrm{~mm}$ radius in two weeks. Reaction on laccase negative.

All species accepted here in Ptychogaster have teleomorphs in Postia, which are characterized by a soft, effused to effused-reflexed or flabelliform basidiomes, a monomitic hyphal system with thin- to slightly to distinctly (e.g. P. floriformis) thick-walled hyphae with clamps, some with small crystals, relatively small, narrowly ellipsoid to subcylindrical spores, a brown rot and occurrence on gymnosperms (with a strong preference for Pinaceae), on which they are saprophytic or mildly parasitic, especially on roots. All species have a bitter taste (sometimes registration takes up to $30 \mathrm{sec}$.). 


\section{Key to the species of Postia with a Ptychogaster anamorph}

1a. Mat whitish to yellow, tawny or brown 2

1a. Mat becoming pink, avellaneous or drab 4

2a. Conidia ellipsoid, $7.5-16.5 \times 4.5-9 \mu \mathrm{m}$ P. balsamea

2b. Conidia smaller, $4.5-8.5(-10) \times 3.5-5 \mu \mathrm{m}$ 3

3a. Conidia (5.5-)6.5-8.5(-10) $\times 3.5-5 \mu \mathrm{m}$. Colony pale ochraceous brown when young, becoming tawny to brown with age. Growth radius $12-25 \mathrm{~mm}$ in 2 weeks P. ptychogaster

3b. Conidia $4.5-7(-8.5) \times 3.5-5 \mu \mathrm{m}$. Colony cream-coloured to yellowish, becoming light brown with age. Growth radius $2-15 \mathrm{~mm}$ in 2 weeks ..P. rennyi

4a. Mat distinctly pink when young, becoming dark reddish brown, conidia $(4.5-) 5.5-8(-10) \times$ $(2.5-) 3-4 \mu \mathrm{m}$ P. floriformis

4a. Mat becoming cinnamon drab to avellaneous, conidia (4.5-)5-7.5 $\times$ $(2.7-) 3-4.5(-5) \mu \mathrm{m}$. P. guttulata

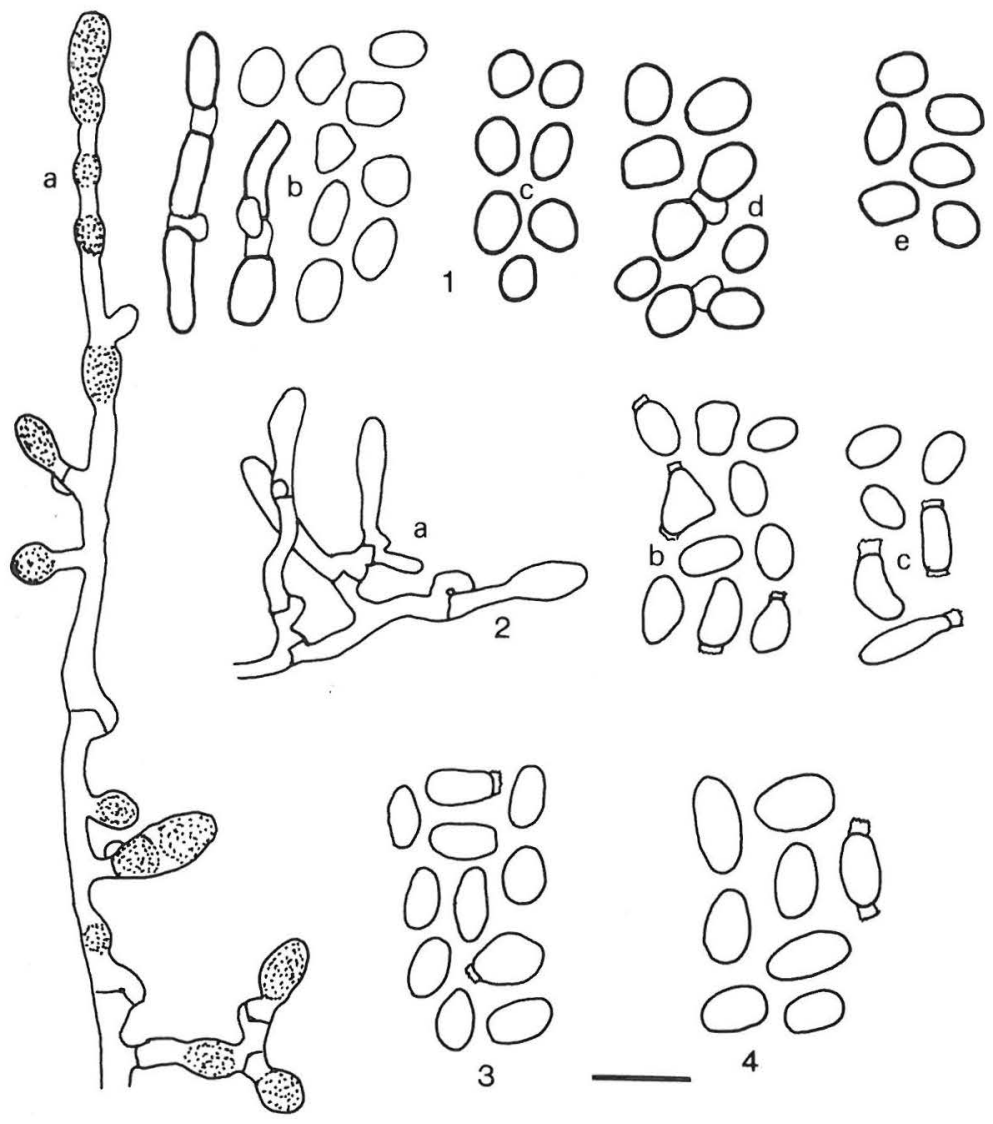

Fig. 1. Postia rennyi (Ptychogaster citrinus): a. conidiophore (CBS 259.74); b. conidia (CBS 929.72); c. conidia of Sporotrichum isabellinum (Karsten 1243); d. conidia of Sporotrichum isabellinum (Karsten 1245); e. conidia (CBS 259.74).

Fig. 2. Postia floriformis (Ptychogaster rubescens): a. conidiophore (CBS 558.85); b. conidia (CBS 559.85); c. conidia (CBS278.89).

Fig. 3. Postia guttulata (CBS 358.33).

Fig. 4. Postia ptychogaster (Ptychogaster fuliginoides) (CBS 144.75). 
Postia balsamea (Peck) Jülich

Colony downy to low cottony, later locally plumose, whitish when young, becoming pinkish buff to cinnamon after 3-4 weeks. Margin appressed, rather dense. Marginal hyphae hyaline, thin-walled, 2-6(-7.5) $\mu \mathrm{m}$ wide, with clamps. Clamps abrupt, often sprouting. Aerial hyphae hyaline, thin-walled, $2-5 \mu \mathrm{m}$ wide. Conidia in chains or in clusters, becoming somewhat thickwalled, brown, ellipsoid, 7.5-16.5 × 4.5-9 $\mu \mathrm{m}$. Growth rate: $10-20 \mathrm{~mm}$ radius in 14 days. Reverse unchanged or darker. Reaction with a-naphthol and p-cresol negative. Odour strong, suggesting iodoform.

The description is mainly from Nobles (1948) as no recent strains were available.

\section{Postia floriformis (Quélet) Jülich}

Anamorph: Ptychogaster rubescens Boudier Fig. 2

Colony downy to low cottony near the margin, powdery to cottony-woolly or locally slightly plumose, whitish when young, Capucine Buff, Pale Ochraceous Buff, Light Ochraceous Salmon or Pale Pinkish Cinnamon, Light Pinkish Cinnamon or Light Vinaceous Cinnamon after two weeks. The mat becomes more compact and then farinaceous, colour finally Avellaneous to Wood Brown to even Snuff Brown. Margin appressed to raised, rather dense. Marginal hyphae hyaline, thin-walled, (1-)1.5-5(-6.5) $\mu \mathrm{m}$ wide, with clamps. Clamps abrupt, often sprouting. Septa sometimes ampullate. Branching equivalent or inequivalent, especially at the narrowest and the widest hyphae, normally from or opposite clamps. Aerial hyphae hyaline, thin-walled, (1-) $1.5-4(-5) \mu \mathrm{m}$, with clamps. some with small crystals. Clamps often sprouting. Some hyphae strongly staining in Cotton Blue, suggesting gloeoplerous hyphae. Submerged hyphae hyaline, thin to somewhat thick-walled, $2-5(-6.5) \mu \mathrm{m}$ wide, often with ampullate septa. Conidia pink in mass, thin-to minutely thick-walled (wall and to a lesser degree cytoplasm strongly cyanophilous, thus easily suggesting a slightly thickened wall), ellipsoid to subcylindrical, sometimes triangular, $(4.5-) 5-8(-10) \times(2.5-) 3-4.5 \mu \mathrm{m}$. Growth rate: $30-$ $39 \mathrm{~mm}$ radius in 14 days. Reverse unchanged. Reaction with a-naphthol negative, with p-cresol positive. Odour absent or insignificant.

P. floriformis in nature is flabellate, often with several pilei originating from a common base.
The colour is reported as white to cream-coloured or greyish, but some may have a rosy tinge. Conidia are often, but not necessarily present. In nature they are reported to be slightly smaller than in culture, viz. 4-6.5 × 3-4.3 $\mu \mathrm{m}$ (Ryvarden \& Gilbertson 1994). The species is also found on timber, where it generally produces conidia in pink hemispherical conidiomata and assumes a pink hue. Molecular studies are necessary for a better understanding of this complex.

Postia guttulata (Peck) Jülich - Fig. 3

Colony powdery to low cottony, locally slightly plumose, whitish when young, becoming Avellaneous to Wood Brown. Margin appressed, rather dense. Marginal and aerial hyphae hyaline, thinwalled, 2-6 $\mu \mathrm{m}$ wide, with clamps. Clamps often sprouting. Some hyphae strongly staining in Cotton Blue, suggesting gloeoplerous hyphae. Conidia ochraceous to pale brown in mass, ellipsoid to subcylindrical, $4.5-7(-7.5) \times 2.5-4.5(-5) \mu \mathrm{m}$.

Postia ptychogaster (F. Ludw.) Vesterh. (= Oligoporus ustilaginoides Bref.)

Anamorph: Ptychogaster pulverulentus (Sowerby) Stalpers comb. nov. Bas.: Auricularia pulverulenta Sowerby, Col. Figs Engl. Fungi 2: 90, pl. 214, 1799. Syn. P. fuliginoides (Pers.) Donk, P. albus Corda; P. flavescens Falck \& O.Falck - Fig. 4

Colonies powdery, becoming Sayal Brown, Ochraceous Tawny, Buckthorn Brown, Cinnamon Buff or Clay Color. Margin narrow, hyaline, hyphae rather dense. Marginal and aerial hyphae hyaline, thin-walled, $1.5-6(-6.5) \mu \mathrm{m}$ wide, with clamps. Clamps often sprouting. Arthroconidia in chains, originating from contracting cytoplasm which forms a new wall and thus becoming separated by empty hyphal parts that contain a clamped septum. Conidia ellipsoid, brownish in mass, thick-walled, (5.5-)6.5-8.5(-10) ×3.5-5 $\mu \mathrm{m}$. Chlamydospores present in submerged mycelium, intercalary, ellipsoid, 7-16 × 4-9 $\mu \mathrm{m}$. Crystals present, both cubical and elongate. Growth rate: $12-25 \mathrm{~mm}$ radius in ChA, significantly less on MEA. Reactions on laccase and tyrosinase negative.

The species is common in nature as a root parasite of preferably Picea, but also of Pinus, on which it forms pustulate conidiomata; the poroid state is usually absent. However, either this species or a close relative with slightly smaller conidia is also found on poles of fences, where it may cause considerable damage. 
When young the conidia are thin-walled and narrowly ellipsoid to sometimes cylindrical, clearly revealing their arthroconidial nature. When maturing, the conidium rounds off and becomes more thick-walled, thus decreasing in length and increasing in width. For these reasons conidial measurements of cultures tend to be longer than those on the natural substrate, reports varying from $4.5-7 \times 3.5-4.5 \mu \mathrm{m}$ (Jahn, 1970 ) to $5-10 \times 3.5-7 \mu \mathrm{m}$ (Ryvarden \& Gilbertson 1994).

Multiporus chlamydoformans O. \& R. Falck (1937) was collected on timber directly below a leaky roof. It produced a white to yellowish white soft fleshy poroid resupinate basidiome, with fibrous structures, hyphae up to $7 \mu \mathrm{m}$ wide and ellipsoid spores, $5 \times 3-3.5 \mu \mathrm{m}$. On agar and on sterile woodblocks a brown Ptychogaster form was produced, besides cushion-shaped structures in which both basidia and conidia were formed. The conidia were given as ellipsoid to nearly cylindrical, 10-15 $\times 9-12 \mu \mathrm{m}$. Type material is not extant, but the description points strongly to Postia ptychogaster. However, the dimensions for the conidia are too large, even considering that the measurements by Falck \& Falck are often a bit overdone.

Postia rennyi (Berk. \& Broome) Rajchenb. (= Oligoporus farinosus Bref.) Anamorph: Ptychogaster citrinus Boud. - Fig. 1 Syn.: Sporotrichum isabellinum P. Karst. Colonies at first downy to low cottony, becoming farinaceous, whitish to cream coloured, becoming yellowish or pale ochraceous, Light Buff or Pinkish Buff, finally more yellowish to pale brown. Margin narrow, hyaline, hyphae rather dense. Marginal and aerial hyphae hyaline, thinwalled, 1.5-6(-8) $\mu \mathrm{m}$ wide, with clamps. Clamps abrupt, often sprouting. Arthroconidia in chains, originating from contracting cytoplasm which forms a new wall and thus becoming separated by empty hyphal parts that contain a clamped septum. Conidia ellipsoid, yellowish in mass, thick-walled, 4.5-7(-8.5) × 3.5-5 $\mu \mathrm{m}$. Crystals present, both cubical and elongate. Growth rate: 2-25 mm radius in ChA, significantly less on MEA. Reactions on laccase and tyrosinase negative.

Oligoporus friesii O. \& R. Falck (1937) was (invalidly) described as a resupinate, whitish to cream-coloured poroid fungus with cream-col- oured chlamydospores which become light brown (tobacco brown) with age. Falck and Falck (1937) draw the conidia as ellipsoid, but give as measurements in the text 5-6 $\times 4.5-5.5 \mu \mathrm{m}$ and in the key $6-8 \times 5-6.5 \mu \mathrm{m}$. The spores are narrowly ellipsoid, $5 \times 2.5-3 \mu \mathrm{m}$. In culture growth is very slow and the fungus grows on Picea. I have no doubt that $O$. friesii is identical with Postia rennyi.

All references to Tyromyces sericeomollis (Romell) Bond. \& Sing. mentioning a conidial stage actually refer to $P$. rennyi.

Discussion: A number of Postia, Oligoporus or Tyromyces species have been mentioned to possess Ptychogaster conidia or chlamydospores. Apart from the four species treated above these are:

a. Postia stiptica (Pers.:Fr.) Jülich. This is a wellknown bluish species on gymnosperms and certainly congeneric with the above recognized Ptychogaster teleomorphs. However, none of the strains available did produce conidia in pure culture. Either chlamydospores may be formed in nature under special conditions, as is the case in many polyporous species, or the record represents a misidentification.

b. Postia ceriflua (Berk. \& M.A. Curtis) Jülich (syn.: T. revolutus (Bres.) Bond. \& Sing.). I do not know this species in pure culture, but it can be confused with $P$. floriformis. It deviates from the Ptychogaster forming species by quite thick-walled tramal hyphae, relatively narrow spores and a preference for angiosperms, although it is also reported from gymnosperms.

Some confusion exists on the species concept in the Postia-Oligoporus species complex that is characterized by narrowly ellipsoid to short cylindrical spores.

a. Oligoporus folliculocystidiatus Kotl. \& Vampola differs from Postia ceriflua in the presence of capitate cystidia (cystidioles) and honey-coloured excretion drops. However, 'cerifluus' means 'with wax-coloured liquid', and thus points to a yellowish excretion product. I am not sure, that these species are really different, the more because the size of the cystidioles is similar or slightly larger than that of the basidia, and a basidiole can also be 
slightly capitate. Thus it may be, that either Polyporus revolutus Bres. is the correct name of Postia ceriflua (incl. O. folliculosocystidiatus), that actually three species are involved or that we are dealing with a single, variable taxon. Both $P$. ceriflua and $O$. folliculocystidiatus are sometimes distinguished from related species by a dorsally attached or pendent basidiome, a character which may be connected with the preferential occurrence in crevices and cavities of very rotten wood. Moreover there are also reports describing it as sessile. In general, references in the literature and herbarium material can only be considered as referring to this complex. Conidia (chlamydospores) have been reported for material under any of these names.

b. The Postia floriformis-guttulata complex consists of species with sessile, effused-reflexed to flabelliform or laterally substipitate basidiomes which may be imbricate. The spores are slightly smaller than in the P. cerifluus complex, and gloeoplerous hyphae are reported for both species; they are also occasionally present in culture. $P$. guttulata can be recognized by the fusiform cystidioles and the buff to brownish pileus surface which is often studded with small pits; the tubes may have a greenish tinge. P. floriformis is smaller and generally described as whitish, becoming straw-coloured. However, material with a slightly pinkish tinge, and occurring on very rotten wood of Picea is also with some doubt referred to this species, following Bourdot \& Galzin (1928). The anamorph of the latter taxon is Ptychogaster rubescens. The reference of von Arx (1973), followed by Stalpers (1978) actually concerns the anamorph of Punctularia atropurpurascens.

c. Tyromyces albidus (Schaeff.) Donk and T. immitis (Peck) Bond. Both names are now generally considered synonyms of $P$. stiptica, but their concept in the litererature has often been rather broad and confusion with Postia guttulata has occurred.

e. Tyromyces destructor (Schrader : Fr.) Bond. \& Singer. Donk (1974) compared the descriptions of Schrader, Fries 1821 and Fries 1838 and concluded that Fries first accepted Schrader's concept, but later changed his mind. The latter concept may well be Postia ptychogaster, but Schrader's fungus grew on rotten domestic timber, was white, fibrous and, when dry, could easily be rubbed to a mealy powder. The word used was 'conterere', which can be translated with rub, destroy, or wear down. Thus it is not stated that the fungus itself is powdery. Finally the fungus destroyed the wood like 'Merulius lacrymans', and thus produced a severe brown rot.There are only few resupinate, poroid, brown rotting basidiomycetes with fibrous mycelium growing in houses, and the most likely candidates for this would be either Antrodia (Fibroporia) vaillantii (DC. : Fr.) Ryvarden or Postia placenta (Fr.) M.J. Larsen \& Lombard, species that actually have been confused. The first is white and forms rhizomorphic strands, but also (sometimes sparse) skeletal hyphae, while the second usually is pinkish (when dry cream-coloured to pale buff), with a fimbriate margin and strictly monomitic. My best guess would be the latter fungus, the more as I am not certain that the pink colour will develop under dark circumstances (it does not in culture). Karsten's concept of this species is Postia rennyi.

f. Tyromyces apalus sensu Bourdot \& Galzin with conidia is $P$. rennyi.

Several related species in different genera do produce thick-walled, chlamydosporous anamorphs, but these are not produced in chains, for example Osteina (Tyromyces) obducta (Berk.) Donk and Parmastomyces mollissimus (R. Maire) Pouzar - Fig. 5.

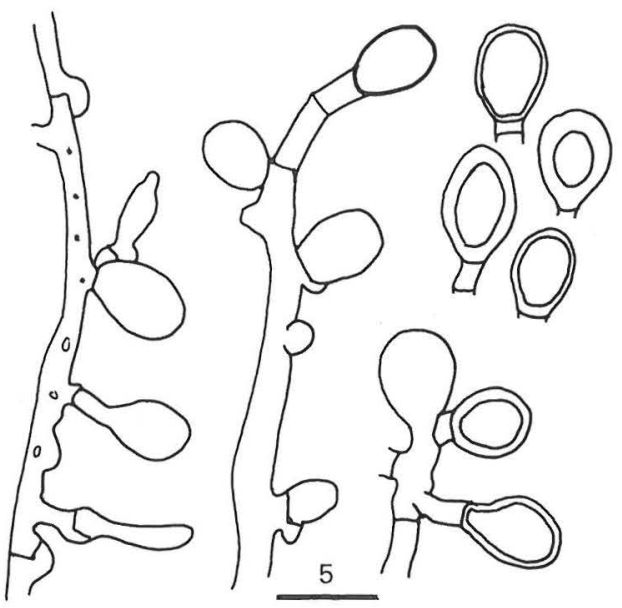

Fig. 5. Parmastomyces mollissimus (CBS 815.72). 


\section{Abortiporus Murrill}

The anamorph of Abortiporus biennis is not closely related to Ptychogaster because of the non-arthric nature of the conidia and the occurrence of a white rot. Sporotrichum differs in the absence of large chlamydospores and a postponed reaction on laccase. The teleomorphs, Postia and Laetiporus resp., are not close to Abortiporus. Consequently a new genus is proposed for the anamorph:

Sporotrichopsis Stalpers gen. nov.

Hyphae hyalinae, fibulatae et hyphae crasse-tunicatae, ramosae, aseptatae. Conidiophorae hyalinae, ramosae ex fibulis. Conidia terminales, plus minusve crasse-tunicatae, globosae vel subglobosae. Putredo alba. Teleomorphosis: Abortiporus.

Species typica: Sporotrichopsis terrestris (S. Schulzer) Stalpers, comb. nov. Ceriomyces terrestris S. Schulzer, Verh. zool.-bot. Ges. Wien 24: 451.1874.

Abortiporus biennis (Bull. : Fr.) Singer

Anamorph: Sporotrichopsis terrestris

(S.Schulzer) Stalpers - Fig. 6

Syn.: Ptychogaster alveolatus Boudier; Ceriomyces schnyderianus Speg.; C. pulchellus Speg.; P. rufescens Lloyd; P. lindtneri Pilát

Margin even, appressed. Colony whitish at first, becoming pinkish, cottony-woolly. Irregular irpicoid to poroid areas formed after 4-6 weeks,

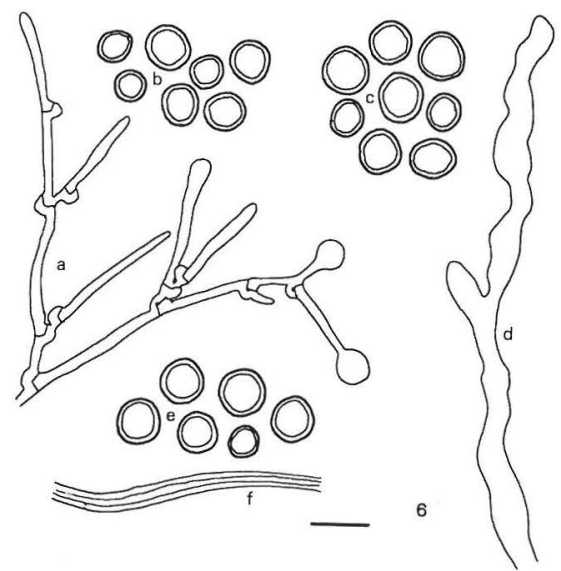

Fig. 6. Abortiporus biennis (Sporotrichopsis terrestris): a. conidiophore (CBS 365.74); b. conidia (CBS 365.74); c. conidia of Ptychogaster alveolatus (type); d. gloeoplerous hypha (CBS 373.59); e. conidia of Ceriomyces schnyderianus (type); f. skeletoid hypha (CBS 365.74). pink. Aerial generative hyphae hyaline, thinwalled, 1.5-6(-7.5) $\mu \mathrm{m}$ wide, with clamps. Thickwalled hyphae hyaline, branched, $1-2.5 \mu$ m wide, without septa and clamps. Gloeocystidia or gloeoplerous hyphae present, contents strongly staining, clavate or irregular, up to $7.5 \mu \mathrm{m}$ wide. Conidiophores hyaline, thin-walled, racemosely branched from clamp connections. Conidia terminal, thick-walled, globose to subglobose, 6-12(14) $\times 5-11(-12) \mu \mathrm{m}$. Growth rate: $50-75 \mathrm{~mm}$ radius in 2 weeks. Reaction on laccase positive.

Anamorphs of two other aphyllophoraceous fungi seem to belong here as well:

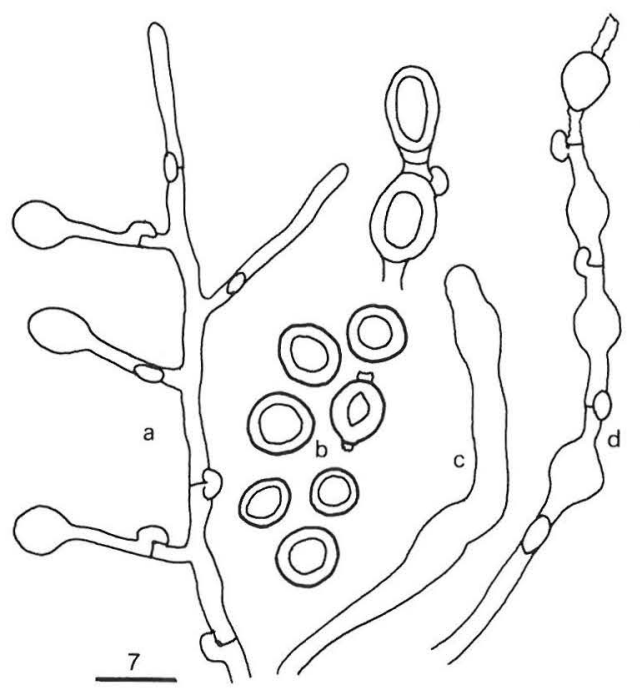

Fig. 7. Granulobasidium vellereum (CBS 165.65): a. conidiophore; b. conidia; c. gloeoplerous hyphae; d. conidia in chain.

1. Granulobasidium vellereum (Ellis \& Cragin) Jülich (Fig. 7). It differs in the absence of the rather narrow, thick-walled hyphae, a slower growth rate (up to $25 \mathrm{~mm}$ radius in 2 weeks), a cottony to plumose mat and a Pale Orange Yellow to Light Buff effused, smooth basidiome. The conidiophores are hardly branched and the conidia are terminal, thick-walled, globose to ellipsoid, $6-11 \times 5.2-8 \mu \mathrm{m}$.

2. Cymatoderma pallens Berthet \& Boidin (Berthet \& Boidin 1966).

3. Oxyporus (Bourd. \& Galz.) Donk Oxyporus obducens (Pers. : Fr.) Donk

Anamorph: Ptychogaster effusus Pat., Journ. Bot. Paris 2: 216 1888. - Fig. 8 


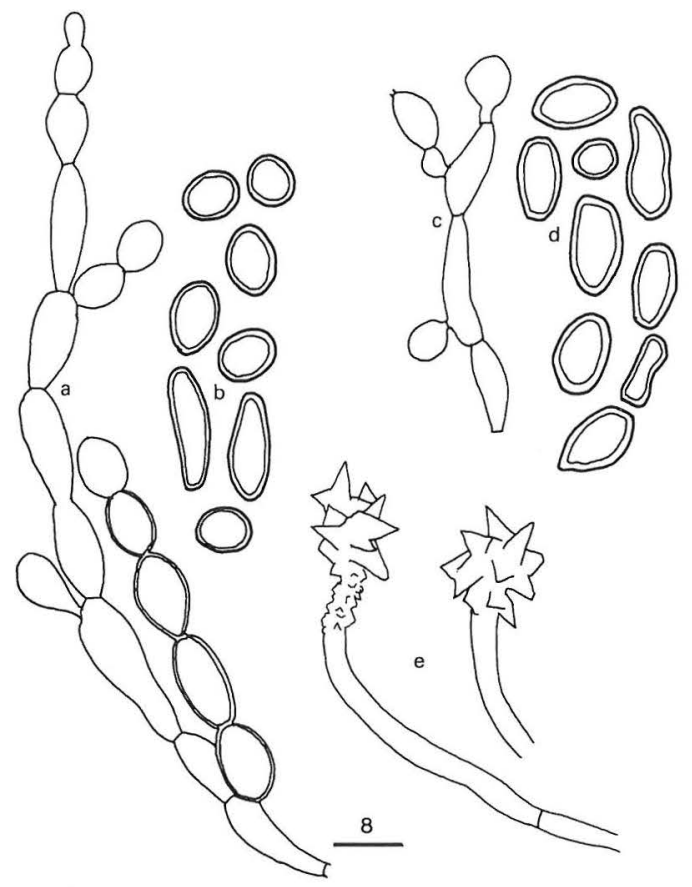

Fig. 8: Oxyporus obducens (Ptychogaster effusus): a-b. conidiophore and conidia (Straus); b-c. conidiophore and conidia (type); e. cystidia (Jahn 1970).

Conidiome resupinate, effused, farinaceous to felty and rather tough, Warm Buff (pale ochraceous). Conidiome surface even, but poroid teleomorph may be present. Hyphal system monomitic. Hyphae hyaline, with thin to usually thickened walls, 1.5-3 $\mu \mathrm{m}$ wide, septate, without clamps. Conidiophores indiscrete, erect, hyaline, thin-walled but becoming thick-walled during development, 3-4.5 $\mu \mathrm{m}$ wide, arising from thickwalled hyphae. Conidia thallic, in simple or branched chains, the younger apical ones hyaline and thin-walled, the older, basal conidia becoming thick-walled. The thickening process continues after liberation. Conidia typically subglobose to ellipsoid, $(6-) 8-12(-15) \times(6-) 6.5-8$ (-9) $\mu \mathrm{m}$, but sometimes nearly cylindrical, $10-21$ $\times$ 4-5.5 $\mu \mathrm{m}$, often with granulose contents. The separation process seems to be schizolytic, there are no sterile cells between the conidia.

The connected basidiome is annual, effused to rarely narrowly pileate, up to $5 \mathrm{~mm}$ thick. Hymenial surface Light Ochraceous Buff to Ochraceous Buff, poroid, 3-5 pores $/ \mathrm{mm}$. Pores regular, dissepiments often somewhat lacerate. Trama Maize Yellow to Pale Orange Yellow, rather soft. Hyphal system monomitic. Tramal hyphae hyaline, thick-walled, 2.5-4(-4.5) $\mu \mathrm{m}$ wide, septate, without clamps. Subhymenial hyphae hyaline, thin- to slightly thick-walled, $1.5-3 \mu \mathrm{m}$ wide. Chlamydospores may be present in the trama, often single, Cystidia developing in the trama, clavate and strongly cyanophilous when young, becoming distinctly capitate and there 3.5-6 $\mu \mathrm{m}$ wide, excreting material over a distance of 10-20 $\mu \mathrm{m}$ or more, sometimes amorphous, but usually as coarse crystals. Subhymenium practically absent. Basidia short cylindrical to pedunculate, 9$14 \times 4.5-5.5 \mu \mathrm{m}$. Spores hyaline, thin-walled, subglobose to broadly ellipsoid, ventrically slightly depressed, 3.5-4.5(-5.5) ×(2.2-)2.5-2.8(-3.2) $\mu \mathrm{m}$, not amyloid, not dextrinoid. On living or dead wood of angiosperms, known from Acer, Aesculus, Populus, Salix, Ulmus. There is also a single record from Pinus.

Discussion: The description is mainly based on European material of Oxyporus obducens, but the type specimen of Ptychogaster effusus fits well. The material falls apart into two groups: those on Salix and Populus with relatively large spores, 4-5.5 $\times 2.6-3.2 \mu \mathrm{m}$, and on other substrates with spores 3.5-4.5 × (2.2-)2.5-2.8 $\mu \mathrm{m}$. Material described by Patouillard (1890) as Poria mollusca Pers., collected from Salix, is also this species.

\section{Ganodermatales}

Ganoderma species have been repeatedly recorded to form internal chlamydospores, often called 'gasterospores'. Under special circumstances, for example a period of drought after formation of a basidiome initial, probably a number of species can produce a chlamydosporic stage, but only a few species do this regularly.

a. Species also known to produce chlamydospores in culture:

G. colossus (Fr.) C.F. Baker, which produces large chlamydospores with spines or sometimes ridges, $16-21 \mu \mathrm{m}$ diam.

G. oerstedii (Fr.) Torrend, chlamydospores smooth, 8-18 $\times 5-11 \mu \mathrm{m}$.

G. rufoalbum Bres. \& Pat. (anamorph: Ptychogaster lycoperdon Pat., P. rufoalbus Pat. and $P$. africanus Lloyd), with subglobose to ovoid or broadly ellipsoid chlamydospores, 7.5-10 × 7-9 $\mu \mathrm{m}$. 
G. weberianum (Bres. \& Henn.) Steyaert, with double-walled chlamydospores with costae (ridges), $11-15 \times 7-10 \mu \mathrm{m}$ (without ornamentation).

b. Species not known in culture:

G. multiplicatum (Mont.) Pat. var. vitalii, chlamydospores $11.5-29 \times 10-14 \mu \mathrm{m}$.

G. rothwellii Steyaert, chlamydospores hyaline to yellowish, 9.5-14 × 7-8 $\mu \mathrm{m}$.

G. subamboinense (Henn.) Bazzalo \& J. Wright with ornamented chlamydospores (Bazzalo \& Wright 1982).

There are also a number of records for $G$. resinaceum; these may actually concern various species, although $G$. resinaceum can form chlamydospores in culture. All chlamydosporic species of Ganoderma seem to have a hymenoderm pileus crust.

\section{Hymenochaetales}

One member of the Hymenochaetaceae repeatedly forms a Ptychogaster anamorph in nature, and a few others at least form abundant chlamydospores in culture.

\section{Inonotus rickii (Pat.) D.A. Reid}

Anamorph: Ptychogaster cubensis Pat. (Fig. 10). Syn.: P. lucidus Lloyd

The conidiome consists of rather soft, fibrous material, that locally is converted into a reddish brown powdery mass. It is xanthochroic (purplish in $\mathrm{KOH}$ ). The hyphae are hyaline to yellowish, thin- to somewhat thick-walled, up to $-8(-10)$ $\mu \mathrm{m}$ wide, without clamps. Chlamydospores globose to ellipsoid, brown, 10-20(-30) $\times 8-12.5 \mu \mathrm{m}$, thick- to very thick-walled (up to $4 \mu \mathrm{m}$ ). Setal hyphae rare to common, subhyaline to brown, acute to rather blunt, up to $300 \times 8 \mu \mathrm{m}$, thick-walled.

Lloyd's material of $P$. lucidus belongs here, despite Lloyd's identification as Polyporus (Ganoderma) lucidus.

P. fici Pat. deviates in several respects. The type material shows only rarely setal hyphae, while these are abundant (and more thick-walled) in the type of $P$. cubensis. The chlamydospores of $P$. fici are more ellipsoid $(14-20(-30) \times 8.5-11$ $(-13) \mu \mathrm{m})$ than those of $P$. cubensis and P. lucidus and the species is collected in Africa, while the other two are from tropical South America.

Phellinus bambusinus Pat. (Fig. 9) forms a different conidial stage: the species produces

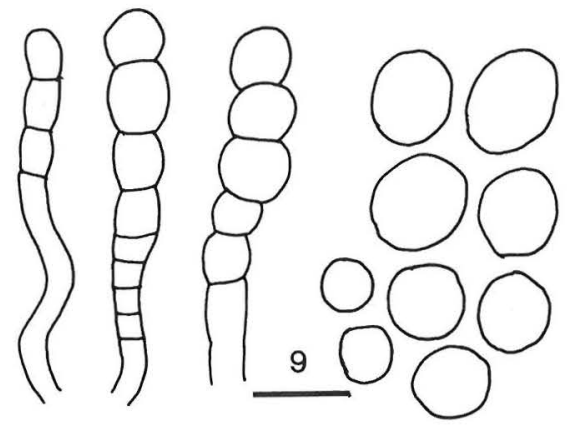

Fig. 9: Phellinus bambusinus (type).

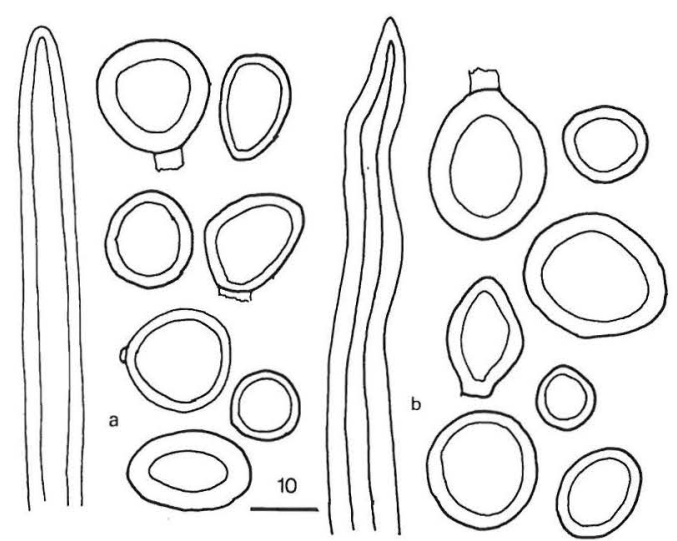

Fig. 10: Inonotus rickii (Ptychogaster cubensis): a. setal hypha and conidia (type); b. setal hypha and conidia of Ptychogaster lucidus (type).

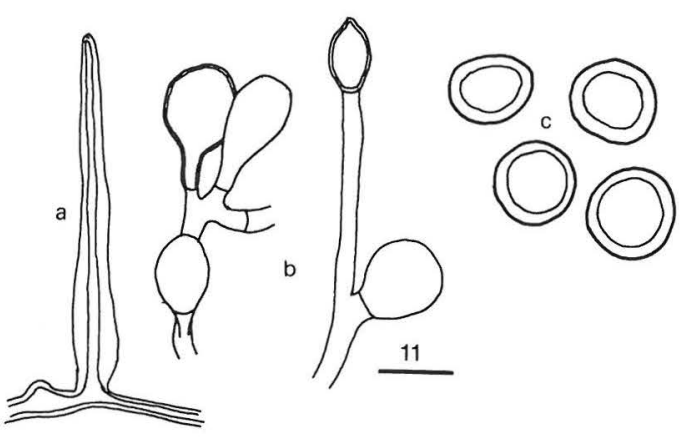

Fig. 11: Hymenochaete rubiginosa (CBS 237.39): a. setal hypha; b. conidiophores; c. conidia.

schizolytic conidia in chains, which show a basipetal development: the apical conidia are the largest, while the basal ones are distinctly arthric, cubical to cylindrical. Mature conidia are subhyaline to brownish, globose to broadly ellipsoid, 
8-14 $\times 7-9 \mu \mathrm{m}$, rather thin-walled. For this species the name Ptychogaster ferruginosus Pat. was cited on the label of the type, but I could not locate a protologue for this name.

Hymenochaete rubiginosa (Dicks. : Fr.) Lév. (Fig. 11) produces setal hyphae and abundant chlamydospores in culture (mainly terminal, globose to broadly ellipsoid, thick-walled, brown, 8 $13 \times 6.5-11 \mu \mathrm{m})$. Such a state is not yet known in nature.

Sporotrichum azureum Wright \& Arx (von Arx 1973) is a later (and thus illegitimate) homonym of S. azureum Link (1809), which is identical with Terana coerulea (Lamarck : Fr.) Kuntze (Stalpers 1984). There is no anamorph genus name available to accomodate this taxon.

\section{Caeruleomyces gen. nov.}

Colonia ochraceo-brunnea in tenebris, caerulescens in lucis. Hyphae hyalinae, tenui-tunicatae, fibulatae. Hyphae laterales dendriticae presentes, 1-2 $\mu \mathrm{m}$ diam. Conidiophorae indiscretae. Conidia terminales, tenui-tunicatae, ellipsoidea vel pyriformia.

Species typica: Caeruleomyces verae Stalpers.

Colonies ochraceous brown when grown in the dark, becoming blue in the light. Hyphae hyaline, thin-walled, with clamps. Dendritic lateral hyphae present, $1-2 \mu \mathrm{m}$ wide. Conidiophores indiscrete. Conidia terminal, thin-walled, ellipsoid to pyriform.

Caeruleomyces verae Stalpers, nom. nov. for Sporotrichum azureum Wright \& Arx in Arx, Persoonia 7: 127, 1973, non $S$. azureum Link.

The name is in honour of Vera Holubová-Jechová, who initiated a search for the teleomorph
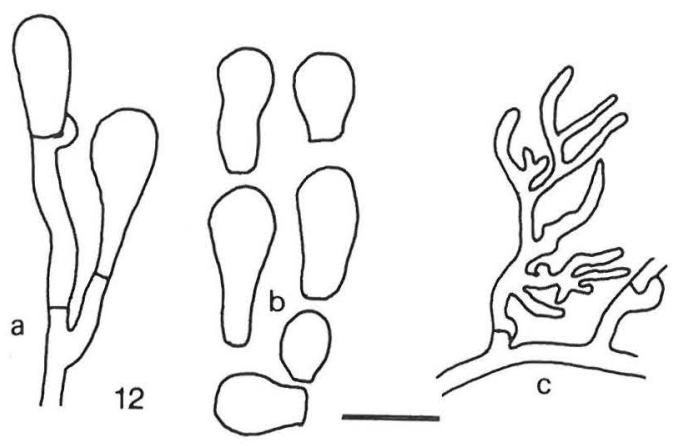

Fig. 12: Caeruleomyces verae (CBS 609.71): a. conidiophore; b. conidia; c. dendritic hypha. of this species, which was interrupted by her untimely death.

Colony appressed, hyaline at first, becoming downy, then farinaceous to velvety. Colour becoming Parula Blue, Delft Blue, Orient Blue or Tyrian Blue, in KOH Dull Violet-Blue to Dusky Dull Violet-Blue. When grown in the dark the colour becomes yellowish brown, assuming bluish tinges within one hour in the light. Margin appressed, hyaline. Marginal hyphae hyaline, thinwalled, $1-2.5(-3) \mu \mathrm{m}$ wide, with prominent clamps. Dendritically branched hyphae distinct, with basal clamp, branchlets $1-1.5(-1.8) \mu$ m wide. Aerial hyphae hyaline, thin-walled, 1.5-3 $\mu \mathrm{m}$ wide, with clamps. Clamps not sprouting. Conidiophores indiscrete, hyaline, thin-walled, branched, each branch producing a terminal conidium. Conidia hyaline to pale yellowish or pale bluish, thin-walled, smooth, pyriform to ellipsoid, sometimes irregular to even subcylindrical, (7-) $8.5-16(-21) \times 4.5-8 \mu \mathrm{m}$. Some arthroconidia may also be present in older parts. Only growing on acidified media (ChA). Reaction on laccase positive, no delayed reaction.

In nature very thick-walled chlamydospores may also be present, globose to subglobose, 15$20 \times 12-18 \mu \mathrm{m}$, walls up to $3.5 \mu \mathrm{m}$ thick. Conidia may also be somewhat different, ellipsoid, 10-15 $\times 6-10 \mu \mathrm{m}$.

\section{Check-list of Ptychogaster and basidiomycet- ous anamorphs of Ceriomyces Corda}

Names of bolets supposed to be combined in Ceriomyces Murrill are omitted.

P. africanus Lloyd, Mycol. Writ. 6: 886. 1919. The material probably belongs to Ganoderma rufoalbum, which is also from Africa.

P. albus Corda, Icon. Fung.: 1838. - Ceriomyces albus (Corda) Sacc., Syll. Fung. 6: 388. 1888. Generally considered to be a synonym of $P$. fuliginioides, the anamorph of Postia ptychogaster.

P. alveolatus Boud., Bull. Soc. mycol. Fr. 4: LV, 1888. - Ceriomyces alveolatus (Boud.) Sacc., Syll. Fung. 9: 201. 1895. A synonym of Ceriomyces terrestris, the anamorph of Abortiporus biennis.

P. aureus Lloyd, Mycol. Writ. 6: 1063, 1921, invalid. The specimen is Sporotrichum versisporum, colonized by an ascomycetous fungus (Stalpers 1978).

C. bogoriensis Holterm., Mykologische Untersuchungen aus den Tropen, p. 98. 1998. Donk 
(1962) considered the species the anamorph of Echinoporia hydnophorus (Berk. \& Br.) Ryvarden, generally known as Echinodia theobromae Pat. (Donk, Taxon 11: 84. 1962).

P. citrinus Boud., J. Bot. (Morot) 1: 8, 1887. Ceriomyces citrinus (Boud.) Sacc., Syll. Fung. 6: 386. 1888 .The anamorph of Postia rennyi.

C. cremaceus Henn., Verh. bot. Ver. Prov. Brandenb. 40: 132. 1899. Type not extant.

P. croceus Lloyd, Mycol. Writ. 7: 1165, 1922, nomen confusum. The type specimen (Lloyd 19995) contains a Boletus sp. covered with Sepedonium chrysospermum.

P. cubensis Pat., Bull. Soc. mycol. Fr. 12: 133. 1896. - Ceriomyces cubensis (Pat.) Sacc., Syll. Fung. 14: 194. 1899. A synonym of P. fici Pat., the anamorph of Inonotus rickii.

P. effusus Pat., Journ. Bot. Paris 2: 216. 1888. Ceriomyces effusus (Pat.) Sacc., Syll. Fung. 9: 202. 1895. The anamorph of Oxyporus obducens (Pers.) Donk.

P. fici Pat., Expl. sci. Tunisie 4: 4. 1892. - Ceriomyces fici (Pat.) Sacc., Syll. Fung. 14: 194. 1899. The anamorph of Inonotus rickii.

C. fischeri Corda, Deutschl. Fl. (ed. J. Sturm) III, 3: 133. 1837. Nomen dubium.

P. flavescens Falck \& O.Falck, Hausschwamm Forschungen 12. 1937, invalid name. A synonym of Ptychogaster fuliginoides (Pers.) Donk.

P. frondosus Lloyd, Mycol. Writ. 7: 1270. 1924, nomen dubium. The type material contains reddish brown labyrinthoid sclerotioid bodies with a textura angularis; some of these cells become thick-walled and for hair-like protuberances.

P. fuliginoides (Pers.) Donk, Proc. K. Ned. Akad. Wet., Ser. C, 75: 170. 1972. - Trichoderma fuliginoides Pers., Syn. Fung. p. 213. 1801. The anamorph of Postia ptychogaster.

C. hepaticus Sacc., Syll. Fung. 6: 388. 1888.Ptychogaster hepaticus (Sacc.) Lloyd, Mycol. Writ. 3, polyporoid issue 2: 32. 1909. Confistulina hepatica (Sacc.) Stalpers, Can. J. Bot. 61: 1660. 1983. The anamorph of Fistulina hepatica (Stalpers \& Vlug 1983).

C. incomptus Sacc., Bull. Soc. mycol. Fr. 5: 115. 1889. The type specimen (no 3501, leg.: 24-IV1889 , PAD) is subglobose, $6-9 \mathrm{~cm}$ diam. and $4.5-$ $6 \mathrm{~cm}$ high, white when fresh, but now ochraceous yellow, smooth, suberose-woody, with brown interior. In section incomplete pores are present, 3$4 / \mathrm{mm}$. Hyphal system is monomitic. Hyphae 2-4 $\mu \mathrm{m}$ wide, often swollen at the septa, without clamps. Setae or setal hyphae absent. Gloeoplerous hyphae present, up to $7 \mathrm{~m}$ wide, with resinous contents. There are many basidiospores, subglobose to ellipsoid, $(5.5-) 6.5-8.5(-9) \times 5.5-$ $6.5 \mu \mathrm{m}$. The specimen grew on wood on Kangaroo Island, Australia. The material may belong to Inonotus.

P. japonicus Lloyd, Mycol. Writ. 5: 681. 1917.Ceriomyces japonicus (Lloyd) Trotter, Syll. Fung. 23: 452. 1925. Nomen dubium. The material is a felty, orange brown clump with a reddish brown crust, consisting of sterile mycelium without clamps.

P. lindtneri Pilát, Bull. Soc. mycol. Fr. 53: 86. 1937. - Ceriomyces lycoperdon Sacc., Syll. Fung. 6: 388. 1888. A synonym of Ceriomyces terrestris, the anamorph of Abortiporus biennis.

P. lucidus Lloyd, , Mycol. Writ. 5: 699. 1917. A synonym of $P$. fici Pat.

P. lycoperdon Pat., J. Bot. (Morot) 1: 113. 1887. The anamorph of Ganoderma rufoalbum.

C. mexicanus De Seynes, Bull. Soc. mycol. Fr. 6: 102. 1890. Type not seen. The specimen is described as cylindrical, capitate, gelatinized, brown, with amyloid hyphae and gloeoplerous hyphae. Conidia ovoid to ellipsoid, 5-6 $\times 4 \mu \mathrm{m}$. The description suggests a member of the Hericiales, but I am not able to suggest a species.

C. neumannii Bres., Annls mycol. 18: 41. 1920. A synonym of Sporotrichum versisporum, the anamorph of Laetiporus sulphureus.

P. niger Lloyd, , Mycol. Writ. 6: 1004. 1920. The type material from Cameroon contains a species of Thelephora, which encrusts a branch over $15 \mathrm{~cm}$ and also forms flabellate pilei. Basidiome is soft fleshy. Pileus surface is black to greyish black, even, somewhat fibrillose. Hymenial surface even, locally rimose, brown to blackish. Subicular hyphae hyaline to brown, thin- to thick-walled, 3-4.5 $\mu \mathrm{m}$ wide, with clamps. Subhymenial hyphae hyaline, thin- to slightly thick-walled, 3.5-5.5(-6) $\mu \mathrm{m}$ wide, with clamps. Basidia clavate, 55-120 × 8-12 $\mu \mathrm{m}$, cyanescent in $\mathrm{KOH}$, with a basal clamp. Spores brown, globose to subglobose, echinulate to aculeate, 9.5$13 \times 9-11 \mu \mathrm{m}$, with large apiculus, spines up to $1(-1.5) \mu \mathrm{m}$ long. The species is Thelephora atra Weinm.

P. nodulosus Pat., Bull. Soc. mycol. Fr. 34: 198. 1920. Type not seen. The material (Baker no 4385) was collected in the Philippines, where it grew on rotten wood. It consisted of nearly hemispherical 
nodules, 3-6 mm diam., white to ochraceous. The hyphae are hyaline, 1-3 m wide, without clamps. The central part desintegrates into numerous cylindrical arthroconidia, $6-10 \times 3 \mu \mathrm{m}$. The teleomorph is hydnoid with small basidia $(12 \times 6 \mu \mathrm{m})$ and smooth, ovoid basidiospores, $3 \times 2 \mu \mathrm{m}$. Cystidia were lacking. Patouillard suggested Acia as a suitable genus for the teleomorph.

C. pulchellus Speg., An. Mus. nac. B. Aires 19: 274. 1909 (generic name published with a question mark). A synonym of Ceriomyces terrestris, the anamorph of Abortiporus biennis.

C. pusillus Sacc., Ann. mycol. 3: 563. 1908, nomen dubium. The type specimen (PAD) contains a lichen with rhizoid structures (probably Peltigera) and an immature, more or less clavate, yellowish body, which shows neither conidia nor clamps. The material is not mature, shows no conidia and is completely covered with a species of Aspergillus.

C. richonii Sacc., Syll. Fung. 6: 388. 1888. Based on Ceriomyces albus sensu Richon. No material seen.

P. rubescens Boud., J. Bot. Paris 1: 10. 1887.Ceriomyces rubescens (Boudier) Sacc., Syll. Fung. 6: 387. 1888. The anamorph of Postia floriformis or a closely related species.

P. rufescens Lloyd, Mycol. Writ. 7: 1195. 1923. A synonym of Ceriomyces terrestris, the anamorph of Abortiporus biennis.

P. rufoalbus Bres. \& Pat., Bull. Soc. mycol. Fr. 5: 79. 1889. The anamorph of Ganoderma rufoalbum Bres. \& Pat. 1914.

C. schnyderianus Speg., An. Soc. Cient. Argent. 9: 285. 1880. A synonym of Ceriomyces terrestris, the anamorph of Abortiporus biennis

C. spongia Speg., An. Soc. Cient. Argent. 10: 132. 1880. The type specimen grew on a trunk of Salix. It is now shivered, blackish brown, without hymenium, but with secondary fungi, which do form conidia. The hyphae are hyaline, agglutinate, somewhat thick-walled, with clamps. Gloeoplerous hyphae rare. The material is a soft polypore, not identifiable on the species level.

C. stuckertii Speg., An. Soc. Cient. Argent. 47:265. 1899.

P. subiculoides Lloyd, Mycol. Writ. 7: 1143, 1922 , nomen confusum. The type specimen from Winnipeg, Canada (no. 19999, Bisby 8-VIII-1921) contains Thelephora (Sebacina) incrustans Fr. (Martin, note on sheet) and a fungus with ornamented spores. Lloyd described globose spores of $32 \mu \mathrm{m}$ diam. which may have been immature basidia of the Sebacina.

C. sulfureus De Seynes, Bull. Soc. bot. Fr. 37: 111. 1890. Nomen novum for Ptychogaster aurantiacus Pat., the anamorph of Laetiporus sulphureus.

C. terrestris Schulzer, Verh. zool.-bot. Ges. Wien 24: 451. 1874.

C. terrestris var. clavatus (Boud.) Sacc. \& Traverso, Syll. Fung. 19: 258. 1910. Nomen nudum. Said to be based on P. clavatus Boud., Icon. mycol. III, where it could not be found. The material is Ceriomyces terrestris, the anamorph of Abortiporus biennis.

P. versisporus (Lloyd) Lloyd, Mycol. Writ. 6: 1005; 1920. - Calvatia versispora Lloyd. Currently classified as Sporotrichum versisporum (Lloyd) Stalpers, the anamorph of Laetiporus sulphureus

C. versicolor De Seynes, Bull. Soc. bot. Fr. 37: 112. 1890. Based on description of a supposed anamorph of Polyporus versicolor L. : Fr. by Patouillard (1883, Tab. anal. fung. 1: 62, no. 143). As no anamorph is known for this common fungus, it is unlikely that the fungus concerned is identical with Trametes versicolor. Either the species is misidentified or - more likely - it concerns a parasite on the polypore. Patouillards drawing can easily be interpreted as a species of the genus Acremonium, which contains taxa parasitic on basidiomycetes.

\section{References}

Arx, J.A. von 1971: Über die Typusart, zwei neue und einige weitere Arten der Gattung Sporotrichum. Persoonia 6: 179-184.

Arx, J.A. von 1973: Further observations on Sporotrichum and some similar fungi. - Persoonia 7: 127130 .

Bazzalo, M.E. \& Wright, J.E. 1982: Survey of the Argentine species of the Ganoderma lucidum complex. Mycotaxon 16: 293-325.

Berthet, P. \& Boidin, J.: Observations sur quelques Hymenomycètes récoltés en République Camerounaise. - Cah. de la Maboké 4: 27-53.

Bourdot, H. \& Galzin, A. 1928: Hyménomycètes de France. - M. Bry, Sceaux.761 pp.

Brefeld, O. 1889: Untersuchungen aus dem Gesammtgebiet der Mykologie 8, Basidiomyceten III: 1-305.

Clements, F.E. \& Shear, C.L. 1931: The genera of Fungi. - Haffner Publ. Co., New York. 496 pp.

Corda, 1838: Icones Fungorum hucusque cognitorum 2: 1-43, pl. 8-15. 
Donk, M.A. 1933. Revision der niederländischen Homobasidiomycetidae - Aphyllophoraceae II. - Meded. Bot. Mus. Herb. R. Univ. Utrecht 9: 1-278.

Donk, M.A. 1960: The generic names proposed for Polyporaceae. - Persoonia 1: 173-302.

Donk, M.A. 1962: The generic names proposed for Hymenomycetes XII. Deuteromycetes. - Taxon 11: 75-104.

Donk, M.A.1974: Check list of European polypores. Verh. K. Ned. Akad. Wet., Afd. Natuurk., Ser. 2, 62: $1-469$.

Falck, R. \& Falck, O. 1937: Die Ptychogasterfäule des Coniferenholz. - Hausschwamm-forschungen 12: 161.

Jahn, H. 1970: Ein resupinater Porling mit Nebenfruchtform: Strangulidium rennyi (B. \& Br.) Pouz. mit Ptychogaster citrinus Romell. - Westf. Pilzbr. 8: 1316.

Nobles, M.K. 1948: Studies in forest pathology. VI. Identification of cultures of wood-rotting fungi. Can. J. Res. C 26: 281-431.
Patouillard, N. 1890: Un nouveau Polypore conidifère. - Naturaliste, sér. II, 12 (68): 146-148.

Patouillard, N. 1900: Essay taxonomique sur les familles et les genres des Hyménomycètes (Thèse). - Lons-leSaunier. $184 \mathrm{pp}$.

Ridgway, R. 1912: Color standards and color nomenclature. - Washington D.C., 43 pp., 53 pl.

Ryvarden, L. \& Gilbertson, R.L. 1994: European Polypores 2: 387-743. - Synopsis Fungorum 7. Fungiflora, Oslo.

Stalpers, J.A. 1978: Identification of wood-inhabiting Aphyllophorales in pure culture. - Stud. Mycol. 16: $1-248$.

Stalpers, J.A. 1984: A revision of the genus Sporotrichum. - Stud. Mycol. 24: 1-105.

Stalpers, J.A. \& Vlug, I.1983: Confistulina, the anamorph of Fistulina hepatica. - Can. J. Bot. 611: 1660-1666. 